\title{
Postharvest decay of strawberry fruit: Etiology, epidemiology, and disease management
}

\author{
E. Feliziani and G. Romanazzi* \\ Department of Agricultural, Food and Environmental Sciences, Marche Polytechnic University, \\ Via Brecce Bianche, Ancona, Italy
}

Received 20 May 2015; accepted 13 October 2015

\begin{abstract}
Strawberry fruit are delicate and succulent, and after harvest they can commonly undergo fungal spoilage. The main strawberry pathogen is Botrytis cinerea, followed by Rhizopus stolonifer, Mucor spp., Colletotrichum spp., Penicillium spp., which are the major pathogens responsible for postharvest decay of strawberry fruit. The traditional strategy of control of postharvest strawberry decay rely on the application of fungicides during the crop growing cycle. Conventional fungicides are applied around flowering, and treatments can be repeated up to harvest. Nowadays, there are many alternatives to conventional fungicides that are characterized by low impact on the environment and on human health. These include biological control agents, natural compounds, decontaminating agents, physical methods, and their combinations. According to an integrated pest-management approach, management of postharvest diseases starts before cultivation in the field, with the suitable choice of the strawberry variety, place of cultivation, and cultivation technique. This continues during the crop development, with weed control, soil sanitation, and management of water and humidity. Careful picking at harvest and then rapid and constant cold storage are the key factors to assure good quality of harvested strawberry fruit. A modified atmosphere that is enriched in ozone, oxygen, or carbon dioxide is frequently used during strawberry storage, to slow down senescence and reduce decay.
\end{abstract}

Keywords: Fragaria $\times$ ananassa, gray mold, soft rot, anthracnose, integrated pest management

\section{Introduction}

Strawberry fruit are particularly perishable, especially after harvest, when even if they are apparently healthy at the time of harvest, they can undergo spoilage. The main causes of decay of strawberry fruit during storage and shelf life are the development of rots that are caused by a range of fungi. The aim of this review is to summarize the information available relating to the etiology and epidemiology of postharvest strawberry diseases. This includes the main strawberry pathogen, Botrytis cinerea, which is the causal agent of gray mold (Fig. 1), and also the many other pathogens that can cause postharvest spoilage, including Rhizopus stolonifer, Mucor spp., Colletotrichum spp., and Penicillium spp. (Fig. 2). The traditional strategy of control of postharvest decay is then described, which is mainly based on field application of synthetic fungicides. A comprehensive report is also presented of the new alternatives to the use of fungicides that are based on biocontrol agents, natural compounds, decontaminating agents, and treatments by physical means.

\footnotetext{
${ }^{*}$ Corresponding author: G. Romanazzi, Department of Agricultural, Food and Environmental Sciences, Marche Polytechnic University, Via Brecce Bianche, 60131 Ancona, Italy. Tel.: +39 071 2204336; Fax: +39 071 2204856; E-mail: g.romanazzi@univpm.it.
} 


\section{Spring wetting initiales fungus growth and sporulation

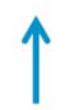

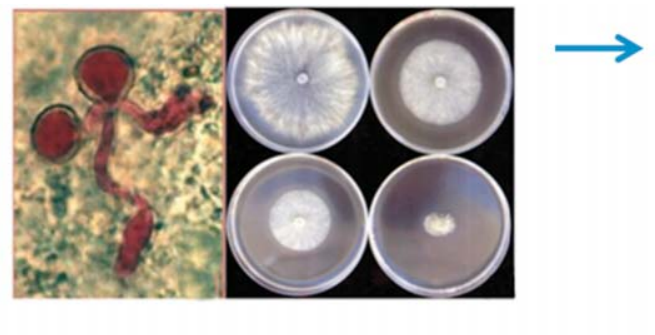

\section{Fungus colonizes and overwinters in organic debris}

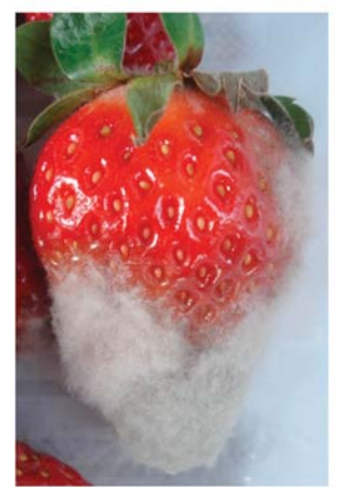

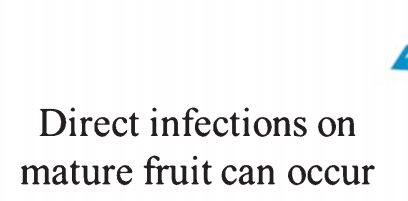

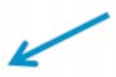

Muture fruit are
covered with fuzzy
conidial masses

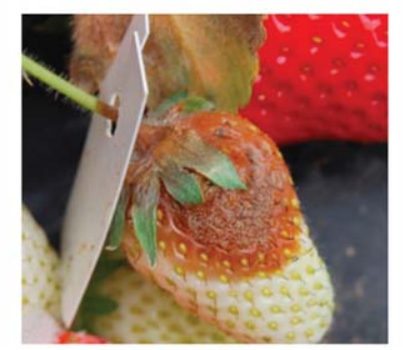

Conidia are disseminated by the wind<smiles>C[Al]1CCC1</smiles>

Infection occur during periods of prolonged moisture

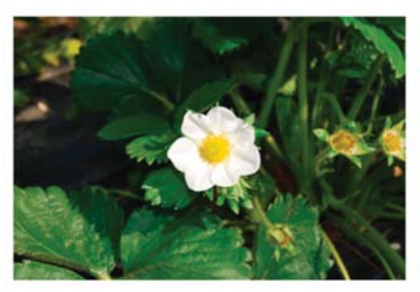

Fungus infects

blossom parts

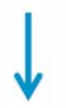

Infection spreads from calix and into green fruit

Fig. 1. Disease cycle of gray mold on strawberry. Modified from Maas et al. (1998) [14].

\section{Gray mold}

\subsection{Etiology}

Botrytis cinerea is the asexual stage (anomorph) of the teleomorph Botryotinia fuckeliana. B. cinerea is a fungus that has a wide range of hosts, which makes it very easy to find as a pathogen in many crops, both preharvest and postharvest. According to a recent review, the fungus $B$. cinerea lies in second place in the word top 10 pathogens listed in terms of its scientific and economic importance [1]. More than 200 dicotyledonous crop species worldwide are estimated to be hosts for $B$. cinerea [2]. Among the strawberry postharvest pathogens, $B$. cinerea is regarded as the most common and important [3].

At the beginning of an infection, a dark circular area is visible where the fruit tissue is softer than the other fruit parts. Subsequently, abundant sporulation can develop from the site of infection, the color of which ranges from white to gray, depending on light exposure. Often, $B$. cinerea can develop from rotted fruit to nearby healthy fruit, causing extensive breakdown of a commodity, and sometimes spoilage of entire batches.

\subsection{Epidemiology}

Infections by $B$. cinerea can occur before harvest, at the field stage, and they can remain latent until storage, when the pathogen takes advantage of the higher relative humidity and lower temperatures for disease development, as these slow down the host defenses. Indeed, pathogen infections can also progress at storage 


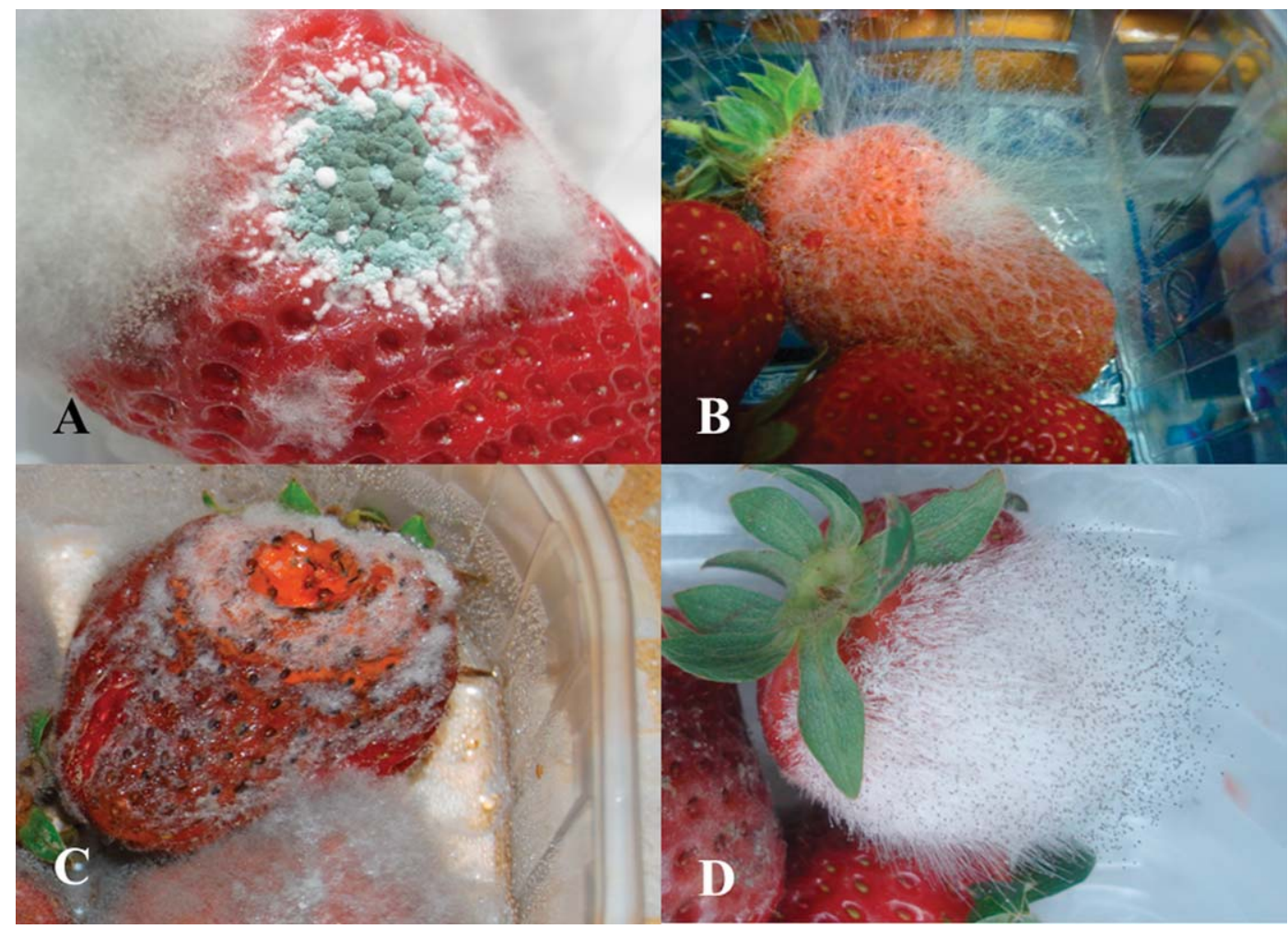

Fig. 2. Postharvest strawberry fruit decay caused by the fungi Penicillium spp. (circular blue and white molds) and Botrytis cinerea (fluffy gray mold) (A), Rhizopus stolonifer (B), Colletotrichum spp. (C), and Mucor spp. (D).

temperatures (usually $0-5^{\circ} \mathrm{C}$ ), when the fruit resistance is decreased. Infection starts from natural openings or mechanical wounds that occur on the fruit.

B. cinerea is present in different habitats as mycelia, microconidia and macroconidia, chlamydospores, sclerotia, apothecia, and ascospores, and these are dispersed by various means [4]. Commonly, B. cinerea dispersal is through the release of its macroconidia in dry air currents [5]. The life cycle of $B$. cinerea comprises the anamorph and teleomorph stages. In the anamorph stage (also known as the somatic or vegetative stage), the mycelium produces asexual conidia (macroconidia), and under difficult environmental conditions, sclerotia, which represent its survival structures [6]. When the environmental conditions return favorable for the fungus, the sclerotia can germinate through the emission of conidiophores, or after the sexual process, through elongation of an apothecium. However, the most frequent mode of sclerotia germination is conidiophore production [4]. In the teleomorph stage (also known as the sexual reproductive cycle), B. cinerea shows large numbers of microconidia in all the crosses that form sexual bodies [7]. Microconidia provide an alternative microscopic propagule for these fungi when they are subjected to adverse conditions. In general, microconidia are found in aging cultures of the fungus, or those that are contaminated by other organisms, and they are associated with sclerotia. Microconidia function primarily as spermatia, and these develop from the germ tubes that are produced by macroconidia, or endogenously, inside empty cells of mature hyphae, or from appressoria and sclerotia [5, 7]. In this sexual stage, after the appropriate preconditions and fertilization by microconidia, the sclerotia can germinate to produce aphotecia, which contain ascospores that result from meiosis [6]. Sexual reproduction of B. cinerea is not common in nature, and it was reported for the first time by Groves and Drayton in 1939 [8], and 
then studied in vitro $[9,10]$. Chlamydospores are short-term survival structures that can help $B$. cinerea to overcome short unfavorable periods that can be encountered on plant surfaces. These are formed by transformation of vegetative mycelium parts, and they are released by hyphal disintegration [5].

In temperate climates, the sclerotia germinate in spring, and serve as a primary source of inoculum within a crop [2]. As well as the sclerotia, during winter or periods that are not favorable for the fungus, mycelia of $B$. cinerea can also survive within infected dead host tissues that are left as crop debris, and also inside seeds, to serve as primary inoculum.

\section{Soft rot}

\subsection{Etiology}

The postharvest disease known as soft rot, black rot, leak, Rhizopus rot, or Mucor rot can be devastating, as the relative etiological fungi can spread rapidly from one infected fruit to the next, healthy, fruit, which can result in extensive breakdown of the commodity. The casual agents belong to the genus Rhizopus, which is usually $R$. stolonifer, and to the genus Mucor [11]. R. stolonifer is considered as one of the fastest-growing fungi, and it has a wide array of hosts that make it one of the most destructive of fungi. Mucor and Rhizopus rots look very much alike and it can be hard to distinguish one from the other in the field. However, using a hand lens and examining the mycelia on the infected fruit, Mucor sporangia are seen to have visible films of viscous liquid on the surface that makes them sticky, whereas Rhizopus sporangia have a dry appearance. During the first day of soft rot infection, the strawberry surface can be covered with thin, fluffy, cotton-like fungal structures. Eventually, sporulation forms a dark mass with black sporangia at their tips, which can cover the entire surface of the fruit [12]. However, the main symptom of soft rot is the deliquescence of the strawberry tissues, which lose their consistency, become water soaked, and exude a leachate. Indeed, infection by $R$. stolonifer and Mucor spp. are closely associated with the enzymatic activities of their polygalacturonases, which can degrade the middle lamellae of the vegetal cells. Polygalacturonases and other enzymes like xylanase, cellulase, and amylase are macerating enzymes that soften the fruit tissues. The percolate that is generated during degradation of the middle lamellae is particularly dangerous for pathogen conidia dispersal within packages that contain strawberry fruit after harvest.

\subsection{Epidemiology}

Rhizopus spp. and Mucor spp. are found naturally in soil, plant debris and the air. Their fungal dispersal mechanisms include wind, air currents, and some invertebrates. Usually, strawberry fruit that are closer to the soil are more susceptible to soft rot. However, rain can easily spread the pathogen spores widely across other vegetal tissues. Indeed, soft rot is more common on strawberry plants exposed to rain in the field or grown under plastic tunnels in several rows, where it can be located along the borders [13]. The pathogens of soft rot are good saprophytes and probably live on crop debris and in the soil between seasons. Zygospores serve as long-term resistance spores, and sporangiospores can remain viable for several months [14].

For infection to occur, $R$. stolonifer and Mucor spp., and others, commonly require mechanical damage to the fruit surface. Once the pathogen has gained entry into a wounded tissue, its mycelia spread around the site of infection very rapidly. The spread of $R$. stolonifer is facilitated by stolons that can attach to the surfaces of the nearby healthy fruit by means of rhizoids.

After harvest, infection and disease development of $R$. stolonifer are controlled by temperature, as the minimum temperature for spore germination and growth is about $6{ }^{\circ} \mathrm{C}$; therefore, rapid cooling of the harvested fruit can control this fungus. However, this is not true for the other pathogens belonging to the genus Mucor spp., which can instead grow and infect the fruit at $0^{\circ} \mathrm{C}$ nearly as well as at $24^{\circ} \mathrm{C}$ [14]. Rapid postharvest cooling is anyway 
always important to maintain fruit quality, even if Mucor spp. is not controlled by these cold temperatures. Increased occurrence of pre and postharvest soft rot have also been associated with the use of certain, even more specific, fungicides to control gray mold [14].

\section{Anthracnose}

\subsection{Etiology}

The disease anthracnose is caused by fungi belonging to the genus Colletotrichum, and especially by Colletotrichum acutatum, which is a quarantine pathogen in some European countries. The main disease symptoms are firm, round, brown lesions on fruit surfaces, which with advanced infections have salmon-colored conidial masses that cover the center of the lesions. The infected fruit eventually dries up and becomes 'mummified' [14].

\subsection{Epidemiology}

The anthracnose pathogen spreads rapidly through fruiting fields during rainy and warm harvest seasons. Spore production, spore germination, and infection of strawberry plants and fruit are favored by warm and humid weather. Infected transplants and contaminated soil are the primary sources of inoculum. The fungi can lie quiescent inside the host tissue for a period, and thus in some cases the infection only becomes visible after harvest. However, during storage, the fungi can only sporadically spread to the nearby fruit.

Anthracnose is difficult to control when the environmental conditions are favorable for infection, and therefore preventive measures must begin at planting. These depend on culture practices that can reduce the inoculum levels and slow the spread of the pathogens in the field. New planting should be established with anthracnose-free plants.

\section{Other postharvest decays}

Penicillium fruit rot is mainly caused by Penicillium expansum, along with some other species of the genus Penicillium, which can cause large postharvest losses in strawberry fruit. However, this disease is sporadic and usually only important locally. Reiterative use of fungicides against gray mold might have increased incidence of rots caused by Penicillium spp.

Aspergillus spp., Alternaria spp. and Cladosporium spp. are the causal agents of postharvest diseases that generally show negligible levels; however, their incidence has increased among cultivars that show resistance to gray mold.

\section{Disease management}

\subsection{Preharvest factors that affect postharvest decay}

According to an integrated pest-management approach, many factors can contribute to the final target of pest control. To manage postharvest diseases, it is important to adopt the right choices, with the first steps applied to the cultivation in the field. To choose the right strawberry variety is of primary importance for successful strawberry fruit production, especially for organic farms. Indeed, in organic production systems, the varieties used must perform well under conditions of fertilization and pest management strategies that are limited and are significantly different from those used during conventional strawberry fruit production. For example, a cultivar with thick cuticles can better resist Rhizopus infection [14]. The choices of plant varieties that are suited to the 
growing area, and of growing areas that are not suitable for the development of pathogens, such as $B$. cinerea or $R$. stolonifer, are fundamental. Regions characterized by warm and dry spring weather or areas where the wind is prevalent at a particular time during the day are to be preferred when the cultivation area is chosen.

Weed management is essential, as excessive weeds reduce the fruit yield and increase the humidity in the field, with some weeds also acting as alternate hosts for these pathogens. Soil solarization or mulches are used to manage weeds. As well as controlling the weeds, mulching serves multiple functions, such as warming or cooling the soil, protecting the fruit and the foliage from the soil, and enhancing the moisture retention. Even if plastic mulches can prevent berry-soil contact, it is important to be sure that water puddles do not form on the plastic under the fruit. The spread of inoculum within a field can be reduced by mulching the middle rows with straw. Cover cropping of legumes is a very old farming practice too, which can provide important benefits to organic strawberry fruit production. Cover crops can improve strawberry cultivation by increasing soil nitrogen availability, reducing soil-borne pest pressure, improving soil physical properties, and reducing soil erosion [15].

For the culture practices, the most important means of inhibiting $B$. cinerea activity is to avoid high humidity and stagnant air, especially in the fruit zone, as these are ideal conditions for fungal development. In outdoor planting for strawberry fruit production, the field should be planned to provide good air circulation patterns. In greenhouse cultivation, heating and ventilation can avoid high humidity conditions. This might require extra venting early in the day when moisture has condensed and before the sunlight has warmed the air.

Sanitation is another fundamental point. To prevent gray mold infection, dead or dying tissue need to be removed from the plants and from the soil surface, both in the field and in the greenhouse. Also, all of the ripe fruit need to be removed during harvest, as well as any fruit with signs of decay or rain damage, and plant debris must not be left under benches or on access paths. At harvest, when the fruit are picked, all of the fruit should be removed from the stem, such that the fleshy receptacle from the end of the fruit is not left behind, as this can support fungal growth. Strawberry plants should also be grown using adequate nitrogen fertilization, as high levels of nitrogen favor pathogen development.

\subsection{Postharvest factors that affect postharvest decay}

Although a lot of effort has been put in by researchers and the food industries to improve and prolong the postharvest life of various produce, low temperature remains the main and most effective means. Rapid and constant cold storage is the key factor to assure good quality of harvested fruit and vegetables. There is a direct relationship between the time between harvest and cold storage and the percentage of decayed fruit during storage: the more rapid the cooling of the harvested produce, the lower the percentage of postharvest decay [16]. In addition, the cold storage needs to be constant, as any interruption of the cold chain can allow the development of a pathogen infection that was quiescent. An interesting study by Boer et al. [17] carried out daily monitoring for fungal growth of Rhizopus spp. isolates on potato dextrose agar when moving samples at various intervals from $3^{\circ} \mathrm{C}$ to expose them to $20^{\circ} \mathrm{C}$ for $2 \mathrm{~h}$, before returning them to $3^{\circ} \mathrm{C}$. Here, there was little difference in the overall fungal growth patterns according to the number of interruptions, which indicates that cold storage only needs to be interrupted once for the fungus to be activated [17].

Humidity is the second parameter to consider during cold storage of the fresh produce, as low relative humidity dehydrates the fruit, while high relative humidity favors fungal growth. Usually, the optimal relative humidity for the storage of strawberry fruit, and for other fruit, is between $90 \%$ and $95 \%$.

During postharvest handling, strawberry fruit have high susceptibility to mechanical damage, and thus they need to be handled with care, to avoid damage that can create an entry point for the decay-causing fungi. For this reason, strawberry fruit are harvested and often packaged in the field. Aliasgarian et al. [18] studied the mechanical damage of strawberry fruit during harvest and postharvest operations, together with some of their physical properties. The results indicated that the variety, operation stage, fruit position in a box, and box position on a truck, have significant effects on the extent of the mechanical damage to the fruit. The maximum damage index was related to the picking stage. The variety 'Gaviota' showed more susceptibility to mechanical damage than 
'Selva'. Maximum damage occurred to the strawberry fruit at the bottom rows in the boxes. Furthermore, it was shown that the higher the position of a box on the truck, the more susceptible the fruit are to mechanical damage.

During storage, the atmosphere where the fruit are stocked can be modified. Within the bags where the fruit are stored, as the fruit respires, the oxygen levels decrease, and the carbon dioxide levels increase [19]. Under these atmospheric conditions, the respiration rate of the fruit is decreased, and as a direct effect, the metabolic processes, including maturation and senescence, are slowed. However, in some cases, there can be adverse effects on color and flavor after exposure to very low oxygen levels and very high carbon dioxide levels [20, 21]. Very high oxygen levels have been tested as an alternative atmosphere for the storage of strawberry fruit [22]. Similarly, atmospheres enriched in gases such as ozone [23, 24], nitric oxide [25, 26], nitrous oxide [27], or hydrogen sulfide [28] have been successfully tested to improve postharvest quality of strawberry fruit.

A modified atmosphere is created when the fruit are sealed in polyethylene bags with relatively low gas permeability. Therefore, simple modified storage with polyethylene film bags could improve the fresh fruit quality, although the gas concentrations in polyethylene bags during storage cannot be controlled accurately. The atmospheric conditions can be regulated partially by the selection of films with different gas permeability [19]. Numerous studies have compared the composition and venting area of a wide range of packaging models [29-31]. In recent years, the demand for new packaging and technologies that are both safe and environmentally sustainable has increased considerably, such as the use of biodegradable or edible coatings. Examples of edible coatings for strawberry fruit are based on chitosan [32] and methylcellulose [33]. As well as being a barrier to mechanical injury, these can have antimicrobial compounds incorporated that can oppose the growth of any microorganisms harbored on the surface of the strawberry fruit, and also nutraceutical compounds that can enhance the value of the produce.

\subsection{Application of conventional fungicides}

Infections by $B$. cinerea that cause postharvest decay usually occur before harvest, in the field, and can remain latent until fruit storage. Due to the lack of infection signs and of effective methods to predict the risk of this disease, preventive applications before the appearance of disease symptoms are recommended. The traditional control of gray mold infection consists of field applications of synthetic fungicides during the crop growing cycle. The fungicides are applied around strawberry plant flowering, and are repeated up to harvest, depending on the weather conditions and the preharvest interval for the respective formulations [34]. Fungicides have been classified by the Fungicide Resistance Action Committee (FRAC) into a number of categories, according to their biochemical modes of action (http://www.frac.info). Several families of synthetic fungicides that can control gray mold infections are available (Table 1). Compounds active against the fungus $B$. cinerea belong to the class of anilinopyrimidines, which includes cyprodinil, mepanipyrim, and pyrimethanil, which block fungal amino-acid synthesis. Fludioxonil and iprodione, which are respectively a phenylpyrrole and a dicarboximide, both inhibit signal transduction in fungal cells. Boscalid and fluopyram, which are respectively a pyridinecarboxamide and a pyridinyl-ethyl-benzamide, prevent energy production, as these both inhibit the enzyme succinate dehydrogenase. Fenhexamid, fenpyrazamine, imidazoles, triazoles, and morpholins are inhibitors of sterol biosynthesis. Pyraclostrobin and fluazinam both inhibit mitochondrial respiration, although they have different mechanisms of action.

B. cinerea is a classical 'high-risk' pathogen, and development of resistance to several classes of fungicides has been frequently reported worldwide. In many countries, the use of some fungicides (e.g., benzimidazole) has been banned or is restricted according to anti-resistance strategies. Mutants of $B$. cinerea that are resistant to fungicides have been isolated in laboratory studies and in the field for many of the active fungicidal agents [35]. As B. cinerea strains that are resistant to fungicides are now very common, this emphasizes the need for accurate adoption of the FRAC guidelines, which suggest a limited number of fungicide applications per year.

Protective broad-spectrum fungicides, or their mixtures, can be used to control soft rot during the fruit-ripening period. The main synthetic fungicides used to control Rhizopus rot are boscalid, fludioxinol, and fenhexamid. 
Table 1

Fungicide ingredients that are active against the fungus B. cinerea, and their classification according to the Fungicides Resistance Action Committee (FRAC)

\begin{tabular}{|c|c|c|c|c|}
\hline Active ingredient & Target action & Target site & FRAC code & FRAC group \\
\hline Cyprodinil & Amino-acid and protein synthesis & Methionine biosynthesis & 9 & Anilino-pyrimidine \\
\hline Mepanipyrim & Amino-acid and protein synthesis & Methionine biosynthesis & 9 & Anilino-pyrimidine \\
\hline Pyrimethanil & Amino-acid and protein synthesis & Methionine biosynthesis & 9 & Anilino-pyrimidine \\
\hline Fludioxonil & Signal trasduction & Histidine kinase (os-2, HOG1) & 12 & Phenylpyrrole \\
\hline Iprodione & Signal trasduction & Histidine kinase (os-1, Daf1) & 2 & Dicarboximides \\
\hline Boscalid & Respiration & $\begin{array}{l}\text { Inhibition of complex II: } \\
\text { succinate-dehydrogenase }\end{array}$ & 7 & $\begin{array}{l}\text { Succinate-dehydrogenase } \\
\text { inhibitors }\end{array}$ \\
\hline Fluopyram & Respiration & $\begin{array}{l}\text { Inhibition of complex II: } \\
\text { succinate-dehydrogenase }\end{array}$ & 7 & $\begin{array}{l}\text { Succinate-dehydrogenase } \\
\text { inhibitors }\end{array}$ \\
\hline Fenhexamid & Sterol biosynthesis in membrane & $\begin{array}{l}\text { 3-Keto reductase in } \\
\text { C4-de-methylation }\end{array}$ & 17 & $\begin{array}{l}\text { Sterol biosynthesis } \\
\text { inhibitor }\end{array}$ \\
\hline Fenpyrazamine & Sterol biosynthesis in membrane & $\begin{array}{l}\text { 3-Keto reductase in } \\
\text { C4-de-methylation }\end{array}$ & 17 & $\begin{array}{l}\text { Sterol biosynthesis } \\
\text { inhibitor }\end{array}$ \\
\hline Imidazoles & Sterol biosynthesis in membrane & $\begin{array}{l}\text { C14-demethylase in sterol } \\
\text { biosynthesis }\end{array}$ & 3 & Demethylation inhibitors \\
\hline Triazoles & Sterol biosynthesis in membrane & $\begin{array}{l}\text { C14-demethylase in sterol } \\
\text { biosynthesis }\end{array}$ & 3 & Demethylation inhibitors \\
\hline Morpholines & Sterol biosynthesis in membrane & $\begin{array}{l}\text { Reductase and isomerase in sterol } \\
\text { biosynthesis }\end{array}$ & 5 & Amines \\
\hline Pyraclostrobin & Respiration & Cytochrome bc1 at Qo site & 11 & $\begin{array}{l}\text { Quinone outside } \\
\text { inhibitors }\end{array}$ \\
\hline Fluazinam & Respiration & Oxidative phosphorylation & 29 & $\begin{array}{l}\text { Uncouplers of oxidative } \\
\text { phosphorylation }\end{array}$ \\
\hline
\end{tabular}

Postharvest Rhizopus rot is controlled by rapidly precooling the strawberry fruit immediately after harvest and maintaining the storage temperature below $6^{\circ} \mathrm{C}$. To help control Mucor fruit rot, all of the ripe fruit should be removed from the field. Sanitary conditions should be maintained during harvesting, packing, transport, and product preparation.

Anthracnose can be partially controlled by applying protective fungicides from flowering through to harvest; however, chemical control is often not sufficient. Most isolates of the pathogen are resistant to benomyl [36].

\subsection{Alternatives to conventional fungicides}

Nowadays, field application of synthetic fungicides remains the most effective and common method to control postharvest rot of fruit and vegetables. However, increasing requests by consumers for fruit and vegetables that are free of fungicide residues has contributed to the interest by researchers and the food industries in the development of alternative methods for controlling postharvest decay of fresh produce. These compounds need to be integrated into, or if possible, to totally replace, the use of synthetic fungicides. Indeed, for some commodities, the application of postharvest fungicides is no longer permitted, due to several normative restrictions, and in general, the use of fungicides is banned in organic agriculture. Also, the appearance of pathogen isolates that are resistant to one or more fungicides has discouraged their repeated use. The following paragraphs summarize some of the alternatives that have been investigated to replace, or to be integrated with, treatments based on conventional fungicides in the control of postharvest strawberry fruit decay. These include: (1) biological control 
agents (BCAs); (2) natural compounds or decontaminating agents; (3) physical methods; and (4) combinations of all of the three previous groups [37, 38].

\subsubsection{Biocontrol agents}

Biological control agents are mainly bacteria and yeast that are 'antagonistic' to the pathogens that cause postharvest strawberry fruit spoilage. These BCAs compete with the pathogens to reduce the availability of nutrients and space, or they parasitize the pathogens by creating antibiosis pressures, through the production of compounds that are sometimes volatile, and that are noxious or unpleasant to the pathogens, or can induce resistance in the host tissue to reinforce the plant defenses against the pathogens [39]. In recent years, numerous studies have been aimed at the isolation and testing of microorganisms that can oppose strawberry pathogens. Table 2 summarizes the most significant of these BCAs, along with the details of the mode of action proposed for each one. Nowadays, several products based on microorganisms are already registered against $B$. cinerea, and not only for strawberry. Among the most popular examples of commercially available biofungicides there are Pseudomonas syringae (BioSave; JET Harvest Solutions, Longwood, FL, USA), Bacillus subtilis (Serenade; Bayer, Leverkusen, Germany), Candida sake (Candifruit; IRTA, Lleida, Spain), and Metschnikowia fructicola (Shemer; Bayer, Leverkusen, Germany).

Compared to postharvest application, field treatments have preventive actions toward infection and development of disease, rather than curative actions, as they allow the antagonist to have longer interactions with the pathogen and to colonize the tissues before the arrival of the pathogen. However, to be successful with preharvest applications, putative biocontrol agents must tolerate low nutrient availability, UV radiation, high temperatures, and dry conditions [40]. Before commercializing a microorganism, it also needs to be shown that it does not have phytotoxic effects, or produce secondary metabolites that can be harmful to human health, while it needs to be effective against postharvest pathogens [41-43].

\subsubsection{Natural substances or decontaminating agents}

Compounds that are 'Generally Recognized As Safe' (GRAS) are known not to be harmful to the environment and to human health according to the United States Food and Drug Administration, and these are used for their antimicrobial properties or their induction of plant defenses. Among the natural compounds proposed, plant extracts and essential oils have been reported to control postharvest diseases, both in vitro and in vivo, and to prolong the overall quality and storage life of fresh commodities [44, 45]. Table 3 summarizes the essential oils and plant extracts that have been tested against postharvest decay of strawberry fruit. In some cases, even if the essential oils are effective in controlling decay, sensory testing must also be carried out before commercialization, as the taste of the strawberry fruit can be affected by the application of essential oils.

Inorganic salts have been shown to be active antimicrobial agents against a range of phytopathogenic fungi, and among these agents, bicarbonates have been proposed as safe and effective alternative means to control postharvest rot of fruit and vegetables, including for strawberry fruit [46]. Also, as well as these salts being non-toxic and having minor environmental impact at their effective concentrations, they are inexpensive [47]. Treatments with formulations that are rich in calcium can reinforce the middle lamellae of the strawberry fruit cells, to increase their resistance toward mechanical and biological injury [13, 48].

Several sanitizers classified as GRAS have been applied to extend postharvest storage of strawberry fruit, including ethanol $[22,38,49]$. Successful results have been obtained using chlorine dioxide to maintain the quality of strawberry fruit [50-52]. One of the most commonly used postharvest treatments to control fungal growth and reduce the respiration rate of strawberry fruit is a modified storage atmosphere where there is carbon dioxide enrichment, to reduce the incidence and severity of decay, and therefore to extend the postharvest life of strawberry fruit. However, in some cases, adverse effects on color and flavor after exposure to very low oxygen and very high carbon dioxide levels have been reported $[20,21]$. Conditions of very high oxygen have been tested as an alternative to conventional modified atmosphere packaging of fruit and vegetables, including for strawberry fruit, as very high oxygen has growth inhibitory effects on bacteria, yeast and molds, and can prevent 
Table 2

Biocontrol agents that have been tested on strawberry tissues either at the preharvest or postharvest stages against Botrytis cinerea and/or Rhizopus stolonifer, and their proposed modes of action

\begin{tabular}{|c|c|c|c|c|}
\hline Biocontrol agent & Target pathogen & $\begin{array}{l}\text { Mode and moment } \\
\text { of application }\end{array}$ & Mode of action & Reference \\
\hline Trichoderma atroviride & B. cinerea & $\begin{array}{l}\text { Spraying on detached, senescing } \\
\text { strawberry leaves, and spraying } \\
\text { under field condition }\end{array}$ & $\begin{array}{l}\text { A combination of } \\
\text { competition for sugars, } \\
\text { production of non-volatile } \\
\text { compounds, and possible } \\
\text { mycoparasitism }\end{array}$ & [87] \\
\hline Halophilic bacteria & B. cinerea & $\begin{array}{l}\text { Strawberry fruit soaked in bacterial } \\
\text { suspension }\end{array}$ & $\begin{array}{l}\text { Production of antifungal } \\
\text { enzymes and volatile } \\
\text { compounds }\end{array}$ & {$[88]$} \\
\hline $\begin{array}{l}\text { Aureobasidium pullulans, } \\
\text { Candida oleophila }\end{array}$ & B. cinerea, $R$. stolonifer & $\begin{array}{l}\text { Spraying at flowering and fruit } \\
\text { maturity under plastic tunnels }\end{array}$ & Competition for nutrients & [89] \\
\hline $\begin{array}{l}\text { Both live and heat-killed } \\
\text { Aureobasidium pullulans }\end{array}$ & B. cinerea & $\begin{array}{l}\text { Wound inoculation of detached green } \\
\text { strawberry fruit, and } \\
\text { dip-inoculation of unwounded } \\
\text { attached green strawberry fruit }\end{array}$ & Enhanced disease resistance & {$[90]$} \\
\hline Trichoderma harzianum & B. cinerea, $R$. stolonifer & $\begin{array}{l}\text { Inoculation of wounded and } \\
\text { unwounded fruit }\end{array}$ & Direct parasitism & [91] \\
\hline Candida intermedia & B. cinerea & $\begin{array}{l}\text { Strawberry fruit dipped in a yeast cell } \\
\text { suspension or exposed to yeast } \\
\text { volatile compounds }\end{array}$ & $\begin{array}{l}\text { Production of volatile } \\
\text { compounds }\end{array}$ & [92] \\
\hline Aureobasidium pullulans & B. cinerea & Strawberry fruit dipped & $\begin{array}{l}\text { Production of antibiotic } \\
\text { compounds }\end{array}$ & [93] \\
\hline Kloeckera apiculata & B. cinerea & Strawberry fruit dipped & Direct parasitism & [94] \\
\hline $\begin{array}{l}\text { Lactobacillus plantarum } \\
\text { combined with cumin oil }\end{array}$ & B. cinerea & $\begin{array}{l}\text { Spraying on wounded strawberry } \\
\text { fruit }\end{array}$ & $\begin{array}{l}\text { Competition for space and } \\
\text { nutrients }\end{array}$ & [95] \\
\hline Pichia carribbica & B. cinerea, $R$. stolonifer & Inoculation of strawberry fruit & Enhanced disease resistance & [96] \\
\hline Rhodotorula glutinis & B. cinerea & $\begin{array}{l}\text { Dipping or inoculation of strawberry } \\
\text { fruit }\end{array}$ & $\begin{array}{l}\text { Competition for space and } \\
\text { nutrients }\end{array}$ & [97-99] \\
\hline Hanseniaspora uvarum & B. cinerea, $R$. stolonifer & $\begin{array}{l}\text { Spraying at } 3 \text { days before harvest in } \\
\text { greenhouses }\end{array}$ & Enhanced disease resistance & {$[100]$} \\
\hline Metschnikowia fructicola & B. cinerea & $\begin{array}{l}\text { Spraying in greenhouses, in low } \\
\text { plastic tunnels, and open-field } \\
\text { culture }\end{array}$ & - & [101] \\
\hline Cryptococcus laurentii & B. cinerea & Field spraying & - & {$[102]$} \\
\hline $\begin{array}{l}\text { Cryptococcus laurentii } \\
\text { combined with hot water } \\
\text { dipping }\end{array}$ & $R$. stolonifer & Inoculation of strawberry fruit & Competition for nutrients & {$[103]$} \\
\hline
\end{tabular}

undesired anoxic fermentation [22, 53-55]. In addition, installation of ozone generators in strawberry cooling rooms has increased over the past few years. Indeed, ozone is considered safe, does not deposit residues on the fruit, is allowed in organic agriculture, and is efficient in the control of postharvest decay [56]. When strawberry fruit were cold stored in experimental atmospheres enriched in ozone, their postharvest quality was maintained longer [23, 24, 55]. 
Table 3

Essential oils and plant extracts that have been tested against postharvest decay of strawberry fruit

\begin{tabular}{|c|c|c|c|c|}
\hline Scientific name & Common name & Target pathogen & Mode of application & Reference \\
\hline Ocimum basilicum & Basil & B. cinerea & - & {$[104,105]$} \\
\hline Lavandula angustifolia & Lavander & B. cinerea, A. niger, $R$. stolonifer & - & [106] \\
\hline Rosmarinus officinalis & Rosemary & Postharvest decay & Microencapsulation & [107] \\
\hline Foeniculum vulgare & Fennel & B. cinerea, A. niger, $R$. stolonifer & - & [106] \\
\hline Thymus vulgaris & Thymus & Postharvest decay & Microencapsulation & {$[107,108]$} \\
\hline Eucalyptus globulus & Eucalyptus & Postharvest decay & Exposure to vapor & [109] \\
\hline Cuminum cyminum & Cumin & B. cinerea, A. niger, $R$. stolonifer & - & {$[105,106]$} \\
\hline Mentha piperita & Peppermint & B. cinerea, A. niger, $R$. stolonifer & - & {$[106]$} \\
\hline Cinnamonum zeylanicum & Cinnamon & Postharvest decay & Exposure to vapor & [109] \\
\hline Urtica dioica & Nettle & B. cinerea, $P$. expansum, $R$. stolonifer & Immersion & [13] \\
\hline Abies sibirica & Fir & B. cinerea, $P$. expansum, $R$. stolonifer & Immersion; field treatments & {$[13,61]$} \\
\hline
\end{tabular}

Resistance inducers are plant or pathogen constituents, or their analogs, that can act as plant elicitors, as they can activate the plant defense mechanisms, and thus simulate the presence of pathogens. Among the resistance inducers, chitosan, salicylic acid and benzothiadiazole have been tested on strawberry fruit. Salicylic acid [57] and the synthetic elicitor benzothiadiazole $[13,58-61]$ have been reported to prolong postharvest life of strawberry fruit and to activate systemic acquired resistance in strawberry plants. Treatments with chitosan have reduced postharvest decay of strawberry fruit when the chitosan was applied at the postharvest stage alone [13, 62, 63], when mixed with other agents [64-66], or when applied at the preharvest stage under controlled conditions in plastic tunnels $[58,62]$ or under field conditions [61, 67]. In addition, when a chitosan coating is applied to the strawberry fruit tissue, this acts as a physical barrier against mechanical injury and water loss [13]. The postharvest life of strawberry fruit can be extended by such coating techniques, as the coatings can act as a physical barrier and eventually as a carrier of antimicrobial compounds, such as essential oils. Many studies have reported on the use of essential oils embedded in a chitosan coating that can enhance the antifungal activity of chitosan $[66,68]$.

\subsubsection{Physical means}

Physical means of fruit and vegetable protection include heat treatment, exposure to UV-C light, hypobaric and hyperbaric treatments, among other measures [38]. Physical treatments can have dual effects on the fruit, as these are active against the pathogen, and at the same time, they can induce host defense responses.

Storage in an environment that has a hypobaric pressure has been successfully demonstrated to reduce postharvest decay of strawberry fruit [69, 70] and to induce resistance in strawberry tissue [71]. Indeed hypobaric conditions result in a reduction in oxygen partial pressure that is responsible for producing mild stress of stored fruit, which can result in induced resistance and delay of fungal decay of strawberry fruit [71]. In addition, reducing the availability of oxygen results in a lower respiration rate for the strawberry tissues, which therefore slows down their metabolic processes, including maturation and senescence. This lower oxygen might even affect the development of a pathogen inoculum present during storage.

Heat treatments are carried out by dipping fruit into hot water or exposing them to hot vapor or air. The duration of the process is variable, depending on the fruit and on the variety. As strawberry fruit are very sensitive, the time and temperature of any heat treatment should be accurately monitored. Some studies have investigated optimal combinations between time and temperature for heat treatments, and they are generally agreed on $44^{\circ} \mathrm{C}$ to $46^{\circ} \mathrm{C}$ for $15 \mathrm{~min}$, as this treatment has shown the best retention of strawberry firmness and maintenance of the initial quality, without development of either off-colors or off-flavors. When strawberries were dipped in water at temperatures higher than $48^{\circ} \mathrm{C}$ for $15 \mathrm{~min}$, the fruit softened and developed an atypical pink pigmentation [72, 
73]. Other studies on strawberry fruit have suggested their rinsing and brushing in a hot-water treatment at $60^{\circ} \mathrm{C}$ for $20 \mathrm{~s}$ [74], or exposure to hot air at $45^{\circ} \mathrm{C}$ for $3 \mathrm{~h} \mathrm{[75].} \mathrm{On} \mathrm{the} \mathrm{other} \mathrm{hand,} \mathrm{treatment} \mathrm{of} \mathrm{strawberry} \mathrm{fruit} \mathrm{with}$ hot water at temperatures lower than $38^{\circ} \mathrm{C}$ did not improve the postharvest fruit quality compared to untreated fruit, independent of the duration of the treatment [76].

Ultraviolet treatment creates a stress condition that results in increased expression of defense-related enzymes, and consequently in reduced fungal rot [77]. This technique using different levels of energy has been used for many fruit and vegetables, including strawberry fruit $[75,78,79]$. Strawberry fruit treated with UV-C doses at $0.50 \mathrm{~kJ} \mathrm{~m}^{-2}$ and $1.00 \mathrm{~kJ} \mathrm{~m}^{-2}$ showed significantly reduced postharvest gray mold following both artificial inoculations and natural infections, in comparison with the nonirradiated controls. In addition, UV-C doses increased the activity of phenylalanine ammonia lyase in the strawberry tissues $12 \mathrm{~h}$ after irradiation; which indicated the activation of metabolic pathways related to the biosynthesis of phenolic compounds [80]. In a recent study, UV-C treatments were carried out in the field using a device made of germicidal lamps that were supported by a metallic frame; it was shown that these treatments did not affect the phytochemical profiles of the strawberry fruit [81]. Even if UV can be effective in controlling postharvest disease of strawberry fruit, public concern remains toward a means that is perceived as potentially harmful.

Ultrasound is one of the newest nonthermal methods that has been tested experimentally to extend the shelf life of fresh fruit, including for strawberry fruit [82]. The effectiveness of ultrasound depends on the wave frequency and power, and on the treatment time. Ultrasound powers of $30 \mathrm{~W}$ and $60 \mathrm{~W}$ for $5 \mathrm{~min}$ to $10 \mathrm{~min}$ for strawberry fruit were shown to be effective for the reduction of mold growth and the extension of the shelf life of strawberry fruit [82].

\subsubsection{Integrated pest management}

Depending on the characteristics of the commodity and on the specific situation, one strategy for the control of postharvest decay of fruit might be more appropriate than another. To overcome the drawbacks that can arise with the use of any single strategy, the integration of different methods might provide additive or synergistic effects for disease control [38, 83]. The future of pest management in agriculture is to integrate many means of control, each of which will need to be characterized by low impact on the environment and on human health. The use of an individual alternative to synthetic fungicides might not be effective enough to obtain complete control of a disease, while the integration of many might replace or reduce the use of conventional fungicides, whereby each means of control provides a portion of the disease reduction.

The recent European Union policies under Directive 128/2009 made integrated pest management mandatory from January 1, 2014. This Directive states that the European Member States need to take all of the necessary measures to promote the use of products with low risk to human health and the environment from among those available to control the various pathogens. In addition, this Directive considers that where there is the risk of development of pathogen resistance against a plant protection measure, the available anti-resistance strategies should be applied to maintain the effectiveness of the products. This can include the use of multiple pesticides with different modes of action, or the integration of several means of pathogen control that might even not include chemical treatments.

\subsection{Future perspectives}

Strawberry fruit are among the most diffused and consumed berries, because of their combined desirable organoleptic characteristics and significant nutritional and healthy values. Indeed strawberry fruit have a remarkable nutritional composition in terms of their contents of minerals, vitamin C, folates, and phenolic substances, most of which are natural antioxidants that contribute to the high nutritional quality of the fruit [84-86]. However, the fruit are very delicate and perishable, and can develop postharvest rots a few days after the harvest.

In the recent years, research efforts have been addressed to obtain safe strawberry fruit with high sensory and nutritional value, while resolving the problem of postharvest decay. 
In the literature, there are many studies available concerning the effectiveness of alternatives to synthetic fungicides for the control of postharvest fruit decay; many of these are characterized by low impact on the environment and human health. The application of many of these compounds have already been integrated into common cultivation practices, and a lot of products as alternatives to synthetic fungicides are available for farmers. Although they are still overall less effective than fungicides in controlling fruit decay, studies on their applicability, and the number/time/concentration of treatments are needed [110]. Investigations on the interactions between host plants and chemicals applied, even at molecular level with transcriptomic and metabolomic approaches, could clarify the changes that occur in host plants following treatments, or the effects of the treatments on the pathogens and to optimize their applications.

Dedicated breeding programs need to be developed to select specific traits of strawberry fruit, such as improved nutritional value and extended shelf life. To reach this goal, together with the sources of variation within the available germplasm, breeders require deep knowledge of the heritability of each trait and the impact of environmental effects on their variability.

The role of research is crucial to provide the strawberry sector with the necessary knowledge and tools to facilitate the development of fruit of high nutritional quality, grown according to environmentally sustainable methods and with competitive costs.

\section{References}

[1] Dean R, van Kan JAL, Pretorius ZA, Hammond-Kosack KE, Di Pietro A, Spanu PD, et al. The Top 10 fungal pathogens in molecular plant pathology. Mol Plant Pathol. 2012;13:414-30.

[2] Williamson B, Tudzynski B, Tudzynski P, van Kan JAL. Botrytis cinerea: The cause of grey mould disease. Mol Plant Pathol. 2007;8:561-80.

[3] Romanazzi G, Feliziani E. Botrytis cinerea. In: Bautista-Baños S, editor. Postharvest decay: Control strategies. Elsevier; 2014, pp. 131-146.

[4] Jarvis WR. Botryotinia and Botrytis species: taxonomy, physiology, and pathogenicity. Winnipeg, Canada: Hignell Printing Limited, 1977.

[5] Holz G, Coertze S, Williamson B. The ecology of Botrytis on plant surface. In: Elad Y, Williamson B, Tudzynski P, Delen N, editors. Botrytis: Biology, Pathology and Control. Heidelberg: Springer; 2007, pp. 9-27.

[6] Beever RE, Weeds PL. Taxonomy and genetic variation of Botritys and Botryotinia. In: Elad Y, Williamson B, Tudzynski P, Delen N, editors. Botrytis: Biology, Pathology and Control. Heidelberg: Springer; 2007, pp. 29-52.

[7] Fukumori Y, Nakajima M, Akutsu K. Microconidia act the role as spermatia in the sexual reproduction of Botrytis cinerea. J Gen Plant Pathol. 2004;70:256-60.

[8] Groves JW, Drayton FL. The perfect stage of Botrytis cinerea. Mycologia. 1939;31:485-9.

[9] Faretra F, Antonacci E. Production of apothecia of Botryotinia fuckeliana (de Bary) Whetz. Under controlled environmental conditions. Phytopathol Mediterr. 1987;26:29-35.

[10] Faretra F, Antonacci E, Pollastro S. Sexual behavior and mating system of Botryotinia fuckeliana, teleomorph of Botrytis cinerea. J Gen Microbiol. 1988;134:2543-50.

[11] Snowdon AL. A color atlas of post-harvest diseases and disorders of fruits and vegetables. Boca Raton: CRC Press; 1990 , pp. 416.

[12] Bautista-Baños S, Bosquez-Molina E, Barrera-Necha LL. Rhizopus stolonifer (Soft rot). In: Bautista-Baños S, editor. Postharvest decay of fruit and vegetables: Control strategies. Elsevier; 2014, pp. 383.

[13] Romanazzi G, Feliziani E, Santini M, Landi L. Effectiveness of postharvest treatment with chitosan and other resistance inducers in the control of storage decay of strawberry. Postharvest Biol Technol. 2013;75:24-7.

[14] Maas JL. Compendium of strawberry diseases, 2nd ed. APS Press, St. Paul. 1998.

[15] Miller PR, Graves WL, Williams WA, Madson BA. Covercrops for California agriculture. Oakland: University of California Division of Agriculture and Natural Resources. Publication 21471; 1989.

[16] Nunes MCN, Brecht JK, Morais AMMB, Sargent SA. Physical and chemical quality characteristics of strawberries after storage are reduced by a short delay to cooling. Postharvest Biol Technol. 1995;6:17-28.

[17] Boer SHJ, Boyd-Wilson KSH, Petley M, Walter M. Influence of cold-storage temperatures on strawberry leak caused by Rhizopus spp. N Z Plant Protect. 2009;62:243-9. 
[18] Aliasgarian S, Ghassemzadeh HR, Moghaddam M, Ghaffari H. Mechanical damage of strawberry during harvest and postharvest operations. World Appl Sci J. 2013;22:969-74.

[19] Kader AA. Regulation of fruit physiology by controlled/modified atmospheres. Acta Hortic. 1995;398:59-70.

[20] Ke D, Goldstein L, O`Mahony M, Kader AA. Effects of short term exposure to low $\mathrm{O}_{2}$ and high $\mathrm{CO}_{2}$ atmospheres on quality attributes of strawberries. J Food Sci. 1991;56:50-4.

[21] Shamaila M, PowrieWD, Skura BJ. Sensory evaluation of strawberry fruit stored under modified atmosphere packaging (MAP) by quantitative descriptive analysis. J Food Sci. 1992;57:1168-72.

[22] Ayala-Zavala JF, Shiow YW, Chien YW, González-Aguilar GA. High oxygen treatment increases antioxidant capacity and postharvest life of strawberry fruit. Food Technol Biotech. 2007;45:166.

[23] Nadas A, Olmo M, García JM. Growth of Botrytis cinerea and strawberry quality in ozone-enriched atmospheres. J Food Sci. 2003;68:1798-802.

[24] Pérez AG, Sanz C, Ríos JJ, Olías R,. Olías JM. Effects of ozone treatment on postharvest strawberry quality. J Agric Food Chem. 1999;47:1652-6.

[25] Soegiarto L, Wills RBH. Effect of nitric oxide, reduced oxygen and elevated carbon dioxide levels on the postharvest life of strawberries and lettuce. Aust J Exp Agr. 2006;46:1097-100.

[26] Wills RBH, Ku VVV, Leshem YY. Fumigation with nitric oxide to extend the postharvest life of strawberries. Postharvest Biol Technol. 2000;18:75-9.

[27] Qadir A, Hashinaga F. Inhibition of postharvest decay of fruits by nitrous oxide. Postharvest Biol Technol. 2001;22:279-83.

[28] Hu LY, Hu SL, Wu J, Li YH, Zheng JL, Wei ZJ, Liu J, Wang HL, Liu YS, Zhang H. Hydrogen sulfide prolongs postharvest shelf life of strawberry and plays an antioxidative role in fruits. J Agric Food Chem. 2012;60:8684-93.

[29] Jorge T de S, Soares AG, Fonseca MJ de O, Barboza HTG, Junior MF, Oliveira AH, et al. Evaluation of packaging and edible coating on postharvest strawberry. Acta Hortic. 2012;1012:533-38.

[30] Peano C, Giuggioli NR, Girgenti V. Effect of different packaging materials on postharvest quality of cv. Envie2 strawberry. Int Food Res J. 2014;21:1129-34.

[31] Sanz C, Pérez AG, Olías R, Olías JM. Quality of strawberries packed with perforated polypropylene. J Food Science. 1999;64:748-52.

[32] Romanazzi G, Feliziani E, Bautista-Baños S, Sivakumar D. Shelf life extension of fresh fruit and vegetables by chitosan treatment. Crit Rev Food Sci Nutr. 2016; (in press), doi: 10.1080/10408398.2014.900474

[33] Nadim Z, Ahmadi E, Sarikhani H, Chayjan RA. Effect of methylcellulose-based edible coating on strawberry fruit's quality maintenance during storage. J Food Process Pres. 2014;1-11.

[34] Feliziani E, Romanazzi G. Preharvest application of synthetic fungicides and alternative treatments to control postharvest decay of fruit. Stewart Postharvest Rev. 2013;3(4):1-6

[35] Myresiotis CK, Karaoglanidis GS, Tzavella-Klonari K. Resistance of Botrytis cinerea isolates from vegetable crops to anilinopyrimidine, phenylpyrrole, hydroxyanilide, benzimidazole, and dicarboximide fungicides. Plant Dis. 2007;91:407-13.

[36] Poling EB. Anthracnose on strawberry: Its etiology, epidemiology, and pathology, together with management strategies for strawberry nurseries: Introduction to the workshop. Hort Science. 2008;43:59-65.

[37] Mari M, Neri F, Bertolini P. Management of important diseases in Mediterranean high value crops. Stewart Postharvest Rev. 2009;5:1-10.

[38] Romanazzi G, Lichter A, Mlikota Gabler F, Smilanick JL. Recent advances on the use of natural and safe alternatives to conventional methods to control postharvest gray mold of table grapes. Postharvest Biol Technol. 2012;63:141-47.

[39] Jamalizadeh M, Etebarian HR, Aminian H, Alizadeh A. A review of mechanisms of action of biological control organisms against postharvest fruit spoilage. EPPO Bull. 2011;41:65-71.

[40] Ippolito A, Nigro F. Impact of preharvest application of biological control agents on postharvest diseases of fresh fruits and vegetables. Crop Prot. 2000;19:715-23.

[41] Wisniewski ME, Wilson CL. Biological control of postharvest diseases of fruits and vegetables: Recent advances. Hort Science. 1992;27:94-8.

[42] Nunes CA. Biological control of postharvest diseases of fruit. Eur J Plant Pathol. 2012;133:181-96.

[43] Oro L, Feliziani E, Ciani M, Romanazzi G, Comitini F. Biocontrol of postharvest brown rot of sweet cherries and population dynamic of Saccharomyces cerevisiae Disva599, Metschnikowia pulcherrima Disva267 and Wickerhamomyces anomalus Disva2 strains. Postharvest Biol Technol. 2014;96:64-8.

[44] Antunes MD, Cavaco AM. The use of essential oils for postharvest decay control. A review. Flavour Fragr J. 2010;25:351-66.

[45] Feliziani E, Santini M, Landi L, Romanazzi G. Pre and postharvest treatment with alternatives to synthetic fungicides to control postharvest decay of sweet cherry. Postharvest Biol Technol. 2013;78:133-8. 
[46] Karabulut OA, Arslan U, Kuruoglu G. Control of postharvest diseases of organically grown strawberry with preharvest applications of some food additives and postharvest hot water dips. J Phytopathol. 2004;152:224-28.

[47] Sanzani SM, Nigro F, Mari M, Ippolito A. Innovations in the control of postharvest diseases of fresh fruits and vegetables. Arab J Plant Prot. 2009;27:240-44.

[48] Rahman MA, Begum MM, Rashid AM. Effect of calcium dips combined with mild heating on postharvest life and quality of strawberry. Int J Postharvest Tec Inn. 2013;3:230-43.

[49] Karabulut OA, Mlikota Gabler F, Mansour M, Smilanick JL. Postharvest ethanol and hot water treatments of table grapes to control gray mold. Postharvest Biol Technol. 2004;34:169-77.

[50] Shin YJ, Song HY, Song BK. Effect of a combined treatment of rice bran protein film packaging with aqueous chlorine dioxide washing and ultraviolet-C irradiation on the postharvest quality of 'Goha' strawberries. J Food Eng. 2012;113:374-79.

[51] Vandekinderen I, Devlieghere F, Van Camp J, Kerkaert B, Cucu T, Ragaert P, et al. Effects of food composition on the inactivation of foodborne microorganisms by chlorine dioxide. Int J Food Microbiol. 2009;131:138-44.

[52] Aday MS, Caner C. Individual and combined effects of ultrasound, ozone and chlorine dioxide on strawberry storage life. LWT Food Sci Technol. 2014;57:344-51.

[53] Wszelaki AL, Mitcham EJ. Effects of superatmospheric oxygen on strawberry fruit quality and decay. Postharvest Biol Technol. 2000;20:125-33.

[54] Zheng Y, Yang Z, Chen X. Effect of high oxygen atmospheres on fruit decay and quality in Chinese bayberries, strawberries and blueberries. Food Control. 2008;19:470-4.

[55] Allende A, Marín A, Buendía B, Barberán FT, Gil MI. Impact of combined postharvest treatments (UV-C light, gaseous $\mathrm{O}_{3}$, superatmospheric $\mathrm{O}_{2}$ and high $\mathrm{CO}_{2}$ ) on health promoting compounds and shelf-life of strawberries. Postharvest Biol Technol. 2007;46: 201-11.

[56] Feliziani E, Romanazzi G, Smilanick JL. Application of low concentrations of ozone during the cold storage of table grapes. Postharvest Biol Technol. 2014;93:38-48.

[57] Babalar M, Asghari M, Talaei A, Khosroshahi A. Effect of pre- and postharvest salicylic acid treatment on ethylene production, fungal decay and overall quality of Selva strawberry fruit. Food Chem. 2007;105:449-53.

[58] Terry LA, Joyce DC. Suppression of grey mold on strawberry fruit with the chemical plant activator acibenzolar. Pest Manage Sci. 2000;56:989-92.

[59] Mazaro SM, Deschamps C, May De Mio LL, Biasi LA, De Gouvea A, Kaehler Sautter C. Postharvest behaviour of strawberry fruits after pre harvest treatment with chitosan and acibenzolar-s-methyl. Rev Bras Frutic. 2008;30:185-90.

[60] Landi L, Feliziani E, Romanazzi G. Expression of defense genes in strawberry fruits treated with different resistance inducers. J Agric Food Chem. 2014;3047-56.

[61] Feliziani E., Landi L., Romanazzi G. Preharvest treatments with chitosan and other alternatives to conventional fungicides to control postharvest decay of strawberry. Carbohydr Polym. 2015;132:111-7.

[62] El Ghaouth A, Arul J, Ponnampalam R, Boulet M. Chitosan coating effect on storability and quality of fresh strawberries. J Food Sci. 1991;56:1618-20.

[63] Reddy BMV, Belkacemi K, Corcuff R, Castaigne F, Arul J. Effect of pre-harvest chitosan sprays on post-harvest infection by Botrytis cinerea and quality of strawberry fruit. Postharvest Biol Technol. 2000;20:39-51.

[64] Vargas M, Albors A, Chiralt A, Gonzalez-Martinez C, Quality of cold-stored strawberries as affected by chitosan-oleic acid edible coatings. Postharvest Biol Technol. 2006;41:164-71.

[65] Hernández-Muñoz P, Almenar E, del Valle V, Velez D, Gavara R. Effect of chitosan coating combined with postharvest calcium treatment on strawberry (Fragaria $\mathrm{x}$ ananassa) quality during refrigerated storage. Food Chem. 2008;110:428-35.

[66] Perdones A, Sánchez-González L, Chiralt A, Vargas M. Effect of chitosan-lemon essential oil coatings on storage-keeping quality of strawberry. Postharvest Biol Technol. 2012;70:32-41.

[67] Romanazzi G, Nigro F, Ippolito A. Effectiveness of pre and postharvest chitosan treatments on storage decay of strawberries. Frutticoltura. 2000;62:71-5.

[68] Mohammadi A, Hashemi M, Hosseini SM. Nanoencapsulation of Zataria multiflora essential oil preparation and characterization with enhanced antifungal activity for controlling Botrytis cinerea, the causal agent of gray mould disease. Innov Food Sci Emerg. 2015;28:73-80.

[69] Romanazzi G, Nigro F, Ippolito A, Salerno M. Effect of short hypobaric treatments on postharvest rots of sweet cherries, strawberries and table grapes. Postharvest Biol Technol. 2001;22:1-6.

[70] Hashmi MS, East AR, Palmer JS, Heyes JA. Pre-storage hypobaric treatments delay fungal decay of strawberries. Postharvest Biol Technol. 2013;77:75-9. 
[71] Hashmi MS, East AR, Palmer JS, Heyes JA. Hypobaric treatment stimulates defence-related enzymes in strawberry. Postharvest Biol Technol. 2013;85:77-82.

[72] García JM, Aguilera C, Jiménez AM. Gray mold in and quality of strawberry fruit following postharvest heat treatment. Hort Science. 1996;31(2):255-7.

[73] Villa-Rojas R, Lòpez-Malo A, Sosa-Morales ME. Hot water bath treatments assisted by microwave energy to delay postharvest ripening and decay in strawberries (Fragaria $\times$ ananassa). J Sci Food Agric. 2011;91:2265-70.

[74] Jing W, Tu K, Shao XF, Su ZP, Zhao Y, Wang S, Tang J. Effect of postharvest short hot-water rinsing and brushing treatment on decay and quality of strawberry fruit. J Food Quality. 2010;33:262-72.

[75] Pan J, Vicente AR, Martínez GA, Chaves RA, Civello PM. Combined use of UV-C irradiation and heat treatment to improve postharvest life of strawberry fruit. J Sci Food Agric. 2004;84:1831-8.

[76] Wang CY. Effect of moist hot air treatment on some postharvest quality attributes of strawberries. J Food Quality. 2000;23:51-9.

[77] Pombo MA, Rosli HG, Martínez GA, Civello PM. UV-C treatment affects the expression and activity of defense genes in strawberry fruit (Fragaria $\times$ ananassa, Duch.). Postharvest Biol Technol. 2011;59:94-102.

[78] Kim JY, Kim HJ, Lim GO, Jang SA, Song KB. The effects of aqueous chlorine dioxide or fumaric acid treatment combined with UV-C on postharvest quality of 'Maehyang' strawberries. Postharvest Biol Technol. 2010;56:254-6.

[79] Jouki M, Khazaei N. Effect of low-dose gamma radiation and active equilibrium modified atmosphere packaging on shelf life extension of fresh strawberry fruits. Food Pack Shelf Life. 2014;1:49-55.

[80] Nigro F, Ippolito A, Lattanzio V, Di Venere D, Salerno M. Effect of Ultraviolet-C light on postharvest decay of strawberry. J Plant Pathol. 2000;82:29-37.

[81] Xie Z, Charles MT, Fan J, Deschênes M, Dubé C. Effects of preharvest ultraviolet-C irradiation on fruit phytochemical profiles and antioxidant capacity in three strawberry (Fragaria $\times$ ananassa Duch.) cultivars. J Sci Food Agr. 2015; in press.

[82] Aday MS, Temizkan R, Büyükcan MB, Caner C. An innovative technique for extending shelf life of strawberry: Ultrasound. LWT - Food Sci Technol. 2013;52:93-101.

[83] Mari M, Neri F, Bertolini P. Novel approach to prevent and control postharvest diseases of fruits. Stewart Postharvest Rev. 2007;3:1-7.

[84] Giampieri F, Alvarez-Suarez JM, Battino M. Strawberry and human health: Effects beyond antioxidant activity. J Agric Food Chem. 2014;62:3867-76.

[85] Giampieri F, Alvarez-Suarez JM, Mazzoni L, Romandini S, Bompadre S, Diamanti J, Capocasa F, Mezzetti B, Quiles JL, Ferreiro MS, Tulipani S, Battino M. The potential impact of strawberry on human health. Nat Prod Res. 2013;27:4-5.

[86] Alvarez-Suarez JM, Mazzoni L, Forbes-Hernandez TY, Gasparrini M, Sabbadini S, Giampieri F. The effects of pre-harvest and post-harvest factors on the nutritional quality of strawberry fruits: A review. J Berry Res. 2014;4:1-10.

[87] Card SD, Walter M, Jaspers MV, Sztejnberg A, Stewart A. Targeted selection of antagonistic microorganisms for control of Botrytis cinerea of strawberry in New Zealand. Australas Plant Pathol. 2009;38:183-92.

[88] Essghaier B, Fardeau ML, Cayol JL, Hajlaoui MR, Boudabous A, Jijakli H, Sadfi-Zouaoui N. Biological control of grey mould in strawberry fruits by halophilic bacteria. J Appl Microbiol. 2009;106:833-46.

[89] Lima G, Ippolito A, Nigro F, Salerno M. Effectiveness of Aureobasidium pullulans and Candida oleophila against postharvest strawberry rots. Postharvest Biol Technol. 1997;10:169-78.

[90] Adikaram NKB, Joyce DC, Terry LA. Biocontrol activity and induced resistance as a possible mode of action for Aureobasidium pullulans against grey mould of strawberry fruit. Australas Plant Pathol. 2002;31:223-9.

[91] Batta YA. Control of postharvest diseases of fruit with an invert emulsion formulation of Trichoderma harzianum Rifai. Postharvest Biol Technol. 2007;43:143-50.

[92] Huang R, Li GQ, Zhang J, Yang L, Che HJ, Jiang DH, Huang HC. Control of postharvest Botrytis fruit rot of strawberry by volatile organic compounds of Candida intermedia. Phytopathology. 2011;101:859-69.

[93] Liu X, Wang J, Gou P, Mao C, Zhu ZR, Li H. In vitro inhibition of postharvest pathogens of fruit and control of gray mold of strawberry and green mold of citrus by aureobasidin A. Int J Food Microbiol. 2007;119:223-9.

[94] Long CA, Yuan G. Kloeckera apiculata strain (34-9) to control Botrytis cinerea during the pre- and postharvest handling of strawberries. Annals Microbiol. 2009;59:77-81.

[95] Zamani-Zadeha M, Soleimanian-Zadb S, Sheikh-Zeinoddina M, Goli SAH. Integration of Lactobacillus plantarum A7 with thyme and cumin essential oils as a potential biocontrol tool for gray mold rot on strawberry fruit. Postharvest Biol Technol. 2014;92:149-56.

[96] Zhao L, Hongyin Z, Li J, Cui J, Zhang X, Ren X. Enhancement of biocontrol efficacy of Pichia carribbica to postharvest diseases of strawberries by addition of trehalose to the growth medium. Int J Mol Sci. 2012;13:3916-32.

[97] Zhang H, Yang Q, Lin H, Ren X, Zhao L, Hou J. Phytic acid enhances biocontrol efficacy of Rhodotorula mucilaginosa against postharvest gray mold spoilage and natural spoilage of strawberries. LWT - Food Sci Technol. 2013;52:110-5. 
[98] Zhang H, Ge L, Chen K, Zhao L, Zhang X. Enhanced biocontrol activity of Rhodotorula mucilaginosa cultured in media containing chitosan against postharvest diseases in strawberries: Possible mechanisms underlying the effect. J Agric Food Chem. 2014;62:421424.

[99] Zhang H, Wang L, Dong Y, Jiang S, Cao J, Meng R. Postharvest biological control of gray mold decay of strawberry with Rhodotorula glutinis. Biol Control. 2007;40:287-92.

[100] Cai Z, Yang R, Xiao H, Qin X, Si L. Effect of preharvest application of Hanseniaspora uvarum on postharvest diseases in strawberries. Postharvest Biol Technol. 2015;100:52-8.

[101] Karabulut OA, Tezcan H, Daus A, Cohen L, Wiess B, Droby S. Control of preharvest and postharvest fruit rot in strawberry by Metschnikowia fructicola. Biocontrol Sci Technol. 2004;14:513-21.

[102] Wei Y, Mao S, Tu K. Effect of preharvest spraying Cryptococcus laurentii on postharvest decay and quality of strawberry. Biol Control. 2014;73:68-74.

[103] Zhang H, Zheng X, Wang L, Li S, Liu R. Effect of yeast antagonist in combination with hot water dips on postharvest Rhizopus rot of strawberries. J Food Eng. 2007;1:281-7.

[104] Marjanlo AA, Mostofi Y, Gilvaie MM. Study on the effect of basil (Ocimum basilicum) essential oil on gray mold control in vitro and on strawberry ('Selva') fruit. Acta Hortic. 2010;877:1511-8.

[105] Asghari MA, Mostofi Y, Shoeibi S, Fattahi M. Effect of cumin essential oil on postharvest decay and some quality factors of strawberry. J Med Plants. 2009;8:25-43.

[106] Hadian J, Ghasemnezhad M, Ranjbar H, Frazane M, Ghorbanpour M. Antifungal potency of some essential oils in control of postharvest decay of strawberry caused by Botrytis cinerea, Rhizopus stolonifer and Aspergillus niger. J Essent Oil Bear Pl. 2008;11:553-62.

[107] Alikhani M, Daraei Garmakhany A. Effect of microencapsulated essential oils on storage life and quality of strawberry (Fragaria ananassa cv. Camarosa). Qual Assur Saf Crop. 2012;4:106-12.

[108] Nabigol A, Morshedi H. Evaluation of the antifungal activity of the Iranian thyme essential oils on the postharvest pathogens of strawberry fruits. Afr J Biotechnol. 2011;10:9864-9.

[109] Tzortzakis NG. Maintaining postharvest quality of fresh produce with volatile compounds. Innov Food Sci Emerg. 2007;8:111-6.

[110] Romanazzi G, Smilanick JL, Feliziani E, Droby S. Integrated management of postharvest gray mold on fruit crops. Postharvest Biol Technol. 2016;113:69-76. 